\title{
The Effect of Jury Experience on Jury Verdicts
}

\section{Charles Chastain \\ University of Arkansas at Little Rock}

Abstract: This study considers the hypothesis that juries with more experience are more likely to convict a defendant than less experienced juries are. The theory, which has wide support among prosecutors and defense attorneys, is tested by taking all the jury trials in the Sixth Judicial District in Arkansas for the years 1978 and 1979, identifying juries with greater experience and those with less experience during those two years, and using statistical analysis to determine the strenght of the relationship. The results indicate that the theory is not statistically supported. An additional analysis was completed to determine if a relationship exists between jury experience and severity of sentence. This theory also could not be supported by the statistical data. The conclusion is reached that no relationship exists between jury experience and jury verdicts, but it is acknowledged that manipulation of the cases which come before the various juries may skew the results of the statistical analysis.

The trial by jury in criminal cases is one of America's most hallowed traditions. Its virtues have been extolled by lawyers, politicians, and laymen alike for our entire history. The right to a trial by jury is guaranteed by the United States Constitution and by the constitutions of all fifty states. It has been held to be one of those guarantees that we "cannot do without and still have justice" by the United States Supreme Court in Duncan v. Louisiana (1968). As finders of facts, juries are considered to be the "reasonable person" required in applying the law.

Practically every defendant who goes to trial opts to have a jury trial rather than leave fate in the hands of a judge. But, are juries as jealous of the rights of the accused as we often believe? Do juries in fact stand in the way of an overzealous prosecutor and thereby instill a sense of democracy in our criminal justice system?

\section{Jury Selection}

The basic provisions for jury selection in Arkansas are found in section 39-205 et. seq. of the Arkansas Statutes Annotated (Supp, 
1979). Veniremen are selected in the Sixth Judicial District by taking a starting point at random and then picking every one-hundredth name from the list of registered voters until a total venire of about 1,440 is selected. From these 1,440 , a judge draws approximately 200 to 300 names by drawing numbers randomly without replacement from a box. These numbers correspond to the names drawn for the original 1,440 veniremen. The clerk then presents to the bailiff for the particular judge the roster of potential jurors for that term who would be consecutively numbered in order of their selection. The bailiff, in turn, "cleans up" the list by calling people to see if they still live in the district and are otherwise eligible for jury duty. Some persons are by law exempted from jury duty, ${ }^{1}$ and these would be deleted from the master list by the bailiff. Having satisfied himself as to the validity of his list, the bailiff then awaits the judge's order to bring in enough potential jurors for a trial, at which time he will call by telephone the persons on his list until he has assurances from thirty to thirty-six persons that they will be present for jury duty the next day. This calling is done the afternoon before a trial the following day in order to avoid, as much as possible, late cancellations by the persons called.

With each new trial the bailiff goes back to his list of 200 to 300 names until he reaches the point that the can no longer produce thirtysix persons in court from that list, at which time a new list is drawn. The original list becomes depleted because of persons' becoming ineligible for the standard reasons, such as moving out of the jurisdiction, and because some persons on the list use up their eligibility. How one uses up one's eligibility varies depending on the particular judge's procedure. In the Sixth Judicial District, one judge excuses potential jurors after they have been called twelve times or have served ten times. Still another excuses veniremen after twelve times called or six months on the list. For two other judges the maximum times called is twenty-four, although one of these replaces veniremen after one year's service. In all cases, a person who has completed his service is not eligible for jury duty again for two years.

Having assembled thirty to thirty-six persons for possible jury duty, the court then proceeds to the voir dire examination, a questioning of the potential jurors to determine their fitness for jury duty in the case at hand. First, the judge questions the people so assembled to determine if there is anyone who should be removed for cause. The attorneys then voir dire the potential jurors, in most cases, twelve at a 
time. After the group of twelve has been questioned, each attorney strikes as many as he chooses peremptorially or for cause, and then the group is restored to its original twelve.

This process continues until twelve persons are found acceptable by both attorneys, or both attorneys use up all of their allotted challenges. ${ }^{2}$ The entire process is ordinarily completed in about thirty minutes. If there is an extraordinary case involved, the judge instructs the bailiff to call more people for jury duty than would otherwise be called. One judge allows the attorneys to voir dire the prospective jurors and decide whether to accept them one at a time until twelve are accepted.

The conventional wisdom of the courthourse is that juries are surrounded by an air of mystery and are unpredictable, even quixotic, in their decisions. ${ }^{3}$

\section{Hypotheses}

Discussions with judges, prosecutors, public defenders, probation officers, and other court-related personnel within the criminal system made it apparent that there was widespread belief that jurors become seasoned or hardened over time by jury service. The intent of this paper is to determine the validity of those beliefs and investigate how the beliefs might affect the action of those involved in the jury selection process. Accordingly, the following hypotheses are offered for consideration: (1) the more times a person serves as a juror, the greater the probability that he or she will vote for a guilty verdict; (2) the more jurors with prior jury service on a given jury, the greater the probability of a guilty verdict.

\section{Methodology}

The case files of the circuit clerk contain a list of all persons called for jury duty and reveal which ones were selected as jurors for each particular case. Thus it is possible to identify jurors with experiencethose who have served previously. Two statistics were considered important for each jury in this study. The first is simply the total number of jurors for each case who had prior jury experience during the court session. The second statistic is the composite jury experience score, which was obtained by adding the times served, including the present case, of all the jurors for a case. For example, a juror serving his fifth time would be counted as a " 5 " in the trial. These composite jury experience scores ranged from 12 to 34 in 1978 and from 12 to 38 in 1979. 
After tabulating the total experience factor and number of jurors with experience for the year 1978 and 1979, the highs and lows in each category were selected to determine if either had any relationship to guilty or not guilty verdicts. For comparison with verdict results, those in the 12 to 19 range were considered low in jury experience and those with a score of 30 or above were considered high in jury experience. Since the jurors-with-prior-experience score would range from 1 to 12 , those in the 0 to 5 category were considered low and those in the 8 to 12 range were considered high.

Appendices A and B present case-by-case data for 1978 and 1979 , revealing the composite jury experience score and the number of jurors with previous experience for each case.

\section{Findings}

Using the $\mathrm{X}^{2}$ test to determine the relationship between composite jury experience scores and guilty verdicts, one finds there is no statistical relationship between the two variables. The same is true if number of jurors with experience is compared to guilty verdicts. (See Tables 1 and 2.)

During the year 1978 there were a total of 31 jury trials in the Sixth Judicial District, 28 of which resulted in a jury verdict. The average composite jury experience score was 21 , and the average number of jurors with experience was 5.0. In 1979, there were 62 jury trials, 60 of which ended in a jury verdict. For those 1979 trials the average composite jury experience score was 23 , and the average number of jurors with experience 5.9. However, in neither year was there any significant difference between the verdicts of juries with high experience and those with low experience. It would appear that the conventional wisdom of the courthouse is not grounded in facts. 


\section{Table 1}

Relationship of Composite Jury Experience Scores to Guilty Verdicts

Sixth Judicial District of Arkansas, 1978 and 1979

1978

Not Guilty

Low

Composite Jury

Experience Scores

$(-20)$

High

Composite Jury

Experience Scores

$(30+)$

$$
\begin{array}{ll}
\mathrm{X}^{2}=.487 & \mathrm{X}^{2}=.30 \\
\mathrm{df}=1 & \mathrm{df}=1
\end{array}
$$

Guilty Not Guilty Guilty

10

1979

$\begin{array}{llll}0 & 2 & 2 & 11\end{array}$

\section{Table 2}

Relationship of Jurors with Experience to Guilty Verdicts 1978 to 1979

1978

1979

Not Guilty Guilty Not Guilty Guilty

Low 3

10 7 24

Composite Jury Experience Scores

$(-20)$

High

0

2

2

Composite Jury

Experience Scores

$(30+)$

$$
\begin{array}{ll}
\mathrm{X}^{2}=.487 & \mathrm{X}^{2}=.30 \\
\mathrm{df}=1 & \mathrm{df}=1
\end{array}
$$




\section{Explanation}

The simplest explanation for the data in Tables 1 and 2 would be that it makes no difference whether or not a juror is serving for the first time. This appears to be too simplistic. One possible explanation for the nonrelationship between jury experience and jury verdict is that the prosecutor may not go to trial with a case unless he is almost sure to win. This explanation is supported by the fact that in 1978 a guilty verdict was reached in 86 percent of all jury trials and in 1979 that figure was 80 percent. Without plea bargaining many criminal cases would be dismissed under the speedy trial requirement because there are too many cases to try all of them. It would appear that the prosecutor elects to "plea bargain" those cases which he is not reasonably assured of winning. Defense attorneys interviewed believe that this is true.

Still another consideration is that, although the jury may have found a person guilty, it may have given a greater or lesser sentence depending on the experience in trials of the jury members. It would take more evidence than is presented here to determine the validity of this theory.

One former prosecutor interviewed indicated that his office tried to make sure that the first few trials by jury in a court session were cases that the prosecutor would be highly unlikely to lose. This approach was based on the assumption that jurors with less experience would tend to be more open to defense arguments. This former prosecutor explained that jurors tend to be "gullible" with their early service, but tend to become hardened as they hear the same arguments used over and over by defense attorneys.

Other factors can benefit the prosecutor with seasoned jurors. First, if the defendant does not take the witness stand on his own behalf, an experienced juror would probably know that he chose not to do so because he had a prior felony record. Second, if there is discussion of a bifurcated trial at the voir dire examination in a noncapital case, a juror who had had that experience before would know that the defendant was going to be tried as an habitual offender. Third, an experienced juror would probably be more likely than one without experience to know that convicted persons in Arkansas serve only a small portion of their actual sentences (usually a little more than one-sixth of the sentence) in prison because of parole and "good time" regulations.

The prosecutor would need only one such juror on each jury in order for the entire panel to know about the above considerations. The prosecutor's first problem, of course, is how to produce a group of 
experienced jurors for his less sure cases without losing the early cases by which they gain experience. The explanation that he does this by using "cinch" cases is a plausable one.

\section{Further Considerations}

Perhaps the greatest concern one would have upon reviewing the 1978 and 1979 jury results would be whether a person can get a fair trial at all in Arkansas. Since the prosecutor "plea bargains" about threefourths of his cases and thereby replaces the judge and jury in the sentencing process, and wins 80 to 85 percent of all cases brought before a jury, it would appear that our hallowed tradition of trial by jury is little more than trial by prosecutor. Note that juries acquitted only four persons in 1978 and twelve in 1979 of all the cases that came to the prosecutorial phase. Apparently the weaker cases are weeded out by the plea-bargaining process, and juries do little more than agree with the prosecutor regarding the remaining ones. Given this, the success of the prosecutor in these "cinch" cases is not as overwhelming as it might first appear.

It would seem that the primary purpose of the jury is merely to set the penalty the accused must pay. To determine whether jury experience affected the actual sentence imposed, a statistical analysis was made comparing the composite jury experience score and number of jurors with experience to severity of sentence. This analysis also showed no relationship as table 3 will indicate.

\section{Table 3}

Relationship of composite jury experience score and jurors with experience to sentencing (1978 and 1979 combined)

\section{Composite Jury}

Experience Score

Sentence Low (12-20) High (27+)

Jurors with Experience Low (0-5) High (7-11)
Relationship of jurors with experience to sentences

(1978 and 1979 combined)

Low

19

15

21

Medium or

16

8

18

High

$$
\mathrm{df}=1 \mathrm{X}^{\mathrm{X}^{2}=.68} \quad \mathrm{df}=1 \mathrm{X}^{2}=.04
$$


One factor which would appear to make the sentence independent of jury experience is known by social scientists as "horizontal overcharging." This type of overcharging by the prosecutor occurs when the defendant is charged with several crimes in order to induce a guilty plea or get a significant jury sentence on one of them. For example, a prosecutor may charge an alleged burglar with both burglary and theft of property or alleged rapist with both kidnapping and rape. In practically all cases like these two examples, a double indictment would be possible so the prosecutor may thereby induce the jury to a more severe sentence by overcharging.

In some instances the prosecutor may get a longer sentence by trying a defendant as an habitual offender. Also, if there are multiple defendants, a prosecutor may insist on trying the most easily convicted one first in order that he may later use that person's testimony against a codefendant without concern for self-incrimination guarantees. The results found in this paper indicate that the prosecutor is capable of manipulating the jury to his advantage in this stage of the proceedings. Defendants who exercise their right to a jury trial may be not better off as a group than those who elect to negotiate a plea of guilty.

\section{Notes}

1. Arkansas Revised Statutes (39-102 (1979 Supp.).

2. The state has 10 peremptory challenges in cases where the potential penalty is death or a life sentence, 6 in all other felony cases, and 3 in misdemeanor cases. The corresponding numbers for the defense are 12, 8, and 3 . See Arkansas Revised Statutes 43-1921 and 43-1922, respectively (1964 Replacement).

3. See, for example, Harry Kalven and Hans Zeisel, The American Jury, Little, Brown, and Co., (Boston: 1966); Ewart Thomas and Anthony Hogue, "Apparent Weight of Evidence, Decision Criteria, and Confidence Ratings in Juror Decision Making," 83 Psychological Review 442-65, (Nov., 1976); Steven Brams and Morton Davis, "A Game-Theory Approach to Jury Selection," 12 Trial 47-49, (December, 1976); James Davis, Norbert Kerr, Robert Atkin, Robert Holt, and David Meek, "The Decision Processes of 6 and 12-Person Mock Juries Assigned Unanimous and Two-Thirds Majority Rules," 32 Journal of Personality and Social Psychology, 1-14,(January, 1975); James Davis, Harold Stasser, Craig Spitzer, and Robert Holt " Changes in Group Members' Decision Preferences During Discussion: An Illustration with Mock Juries," 34 Journal of Personality and Social Psychology 1177-87, (Nov., 1976); Roy Stanley, “Arkansas' Key-Man Jury Selection Procedures: Opportunity for Discrimination," 30 Arkansas Law Review 529-36, (Winter, 1977); Richard L. Schott, "Trial by Jury. Reflections of a Juror," 13 Trial 56-59, (May, 1977); Edwin Kennebeck, Juror Number Four. The Trial of Thirteen Black Panthers as Seen from the Jury Box, Norton Press, (N. Y.: 1973); Alice M. Padawer-Singer and Allen H. Barton, "The Impact of Pre-Trial Publicity on Jurors' Verdicts," in The Jury System in America, Rita Simon, editor, Sage Publications, (Beverly Hills: 1975), pp. 125-39; Charles W. Joiner, "From the Bench," Philip H. Corboy, "From the Bar," and Gene Graham, "From the Press," all in The Jury System in America, supra, pp. 145-57, 181-95, and 199-215, respectively; William Pabst, Jr., G. Thomas Munsterman, and Chester H. Mount "The Value of Jury Duty. Serving is Believing," 61 Judicature 38-42, (June-July, 1977); and John P. Richert, "A New Verdict on Juror Willingness," 60 Judicature 496-501, (May, 1977). 


\section{Appendix I}

\section{Case by Case Jury Experience and Sentence Data, Sixth Judicial Circuit in Arkansas, 1978 Effect of Jury Experience Revisited}

Case No. Crime

$78-134$

$78-424$

$78-428$

$78-165$

$78-312$

$78-402$

$78-267$

$78-291$

$78-290$

$78-101$

ठ̀ $78-616$

$78-288$

$78-847$

$78-311$

$78-262$

$78-1077$

$78-980$

$78-850$

$78-532$

$78-1214$

$78-1277$

$78-1189$

$78-1620$

$78-1556$

$78-1360$

$78-19$

Rape

Theft

Rape

Rilpo
Robbery ( 2 counts)

Theft of Property

Theft by Receiving

Forgery - 2nd degree

Aggravated Robbery

Rape and Kidnapping

Public Servant Bribery

First Degree Murder

Aggravated Robbery

Aggravated Robbery

Aggravated Robbery \& Theft

Aggravated Robbery

Sale of phencyclidine

Aggravated Robbery \& Theft

First Degree Battery

Delivery of Cociane

Delivery of Heroin

Aggravated Robbery

Aggravated Robbery and

Attempted Capital Felony Murder

First Degree Battery

Burglary and Theft

Delivery of Cociane
Sentence

8 years plus 8 years not guilty

1 year and 6 months

$\$ 500$ fine

Life

24 years

5 years plus 2 years

$\$ 3000$ fine

9 years

$\$ 2550$ fine

8 years

5 years

5 years plus 2 years

Lifi

\$2500 fine

20 years

6 years plus 2 vears

15 years

5 years

5 years

not guilty

not guilty

8 years

24 years

5 years

10 years
Sentence level

Jury total

Jurors with experience

$\begin{array}{ll}\text { medium } & 12 \\ \text { low } & 18 \\ \text { low } & 21 \\ \text { low } & 22 \\ \text { high } & 24 \\ \text { medium } & 23 \\ \text { low } & 28 \\ \text { low } & 34 \\ \text { low } & 26 \\ \text { low } & 27 \\ \text { low } & 28 \\ \text { low } & 29 \\ \text { low } & 32 \\ \text { high } & 22 \\ \text { low } & 25 \\ \text { medium } & 12 \\ \text { low } & 17 \\ \text { high } & 19 \\ \text { low } & 18 \\ \text { low } & 14 \\ \text { low } & 15 \\ \text { low } & 20 \\ \text { medium } & 19 \\ \text { ligh } & 18 \\ \text { low } & 23 \\ \text { low } & 12\end{array}$




\section{Appendix II \\ Case by Case Jury Experience and Sentence Data, Sixth Judicial Circuit in Arkansas, 1979}

$\begin{array}{ll}\text { Case No. } & \text { Crime } \\ 78-2189 & \text { Aggravated Robbery \& Theft } \\ 78-1714 & \begin{array}{l}\text { Aggravated Robbery } \\ \text { (Habitual Offender) }\end{array} \\ 77-2286 & \text { Aggravated Robbery (2 counts) } \\ 78-1268 & \text { Robbery } \\ 78-1723 & \text { Aggravated Robbery } \\ & \text { (Habitual Offender) } \\ 77-1944 & \text { Capital Murder \& Kidnapping } \\ & \\ 78-962 & \text { Rape } \\ 78-2115 & \text { Rape (3 counts) } \\ & \\ 78-2411 & \text { First Degree Murder } \\ 78-2279 & \text { Aggravated Robbery } \\ 79-0134 & \text { Burglary } \\ 78-2343 & \text { Burglary \& Theft } \\ 78-0374 & \text { Aggravated Robbery, Rape, } \\ & \text { Kidnapping } \\ 79-0163 & \text { Breaking or Entering } \\ 79-0708 & \text { Rape } \\ 79-0530 & \text { Aggravated Robbery } \\ & \text { (Habitual Offender) } \\ 79-0572 & \text { Aggravated Robbery (2 counts) } \\ 78-2086 & \begin{array}{l}\text { Aggravated Robbery and } \\ \text { Attempted Capital Murder }\end{array} \\ 79-0775 & \text { Burglary } \\ 78-2084 & \text { Aggravated Robbery } \\ 78-2341 & \text { First Degree Murder } \\ & \end{array}$

\section{Sentence}

5 years plus 2 years

20 years

not guilty

5 years

50 years

life without parole plus 15 years

35 years

10 years plus 10 years plus 10 years

25 years

7 years

3 years

15 years plus 5 years

not guilty

not guilty

25 years

35 years

30 years plus 30 years

20 years plus 24 years

3 years

15 years

20 years
Sentence level

low

medium

low

low

high

medium

high

medium

medium

low

low

high

low

low

medium

medium

high

low

low

medium

medium
Jury total

Jurors with experience

12

14

0

2

3

0

0

2

6

0

4

10

4

6

4

0

0

4

6 


\section{Appendix II (continued)}

\begin{tabular}{ll} 
Case No. & Crime \\
\hline $79-0124$ & Burglary and Theft \\
$79-0905$ & Burglary and Theft \\
$79-0523$ & Rape \\
$78-0247$ & Second Degree Murder \\
$79-0315$ & Burglary and Theft \\
$79-0306$ & Aggravated Robbery and \\
& Attempted Capital Murder \\
$79-0149$ & Delivery of Dilaudid \\
& (2 counts) \\
$79-0341$ & Burglary \\
$79-0427$ & Theft by Receiving \\
$79-0715$ & First Degree Murder \\
$78-2102$ & Rape \\
$78-1631$ & Aggravated Robbery \\
$79-0527$ & Aggravated Robbery \& Theft \\
$79-1105$ & Aggravated Robbery \\
$78-1416$ & Robbery \\
$79-0102$ & Aggravated Robbery \& \\
& Attempted Capital Murder \\
$78-1570$ & Burglary, Aggravated Robbery \\
& and Rape \\
$79-0515$ & Second Degree Murder \\
$79-0177$ & Aggravated Robbery and Rape \\
$78-2085$ & Aggravated Robbery \\
$79-0803$ & Kidnapping and Rale \\
$78-1723$ & Aggravated Robbery \\
$79-0956$ & Theft \\
$79-1097$ & Possession of Firearm by \\
$79-0995$ & Felon \\
$79-1458$ & Aggraluated Robbery. Rape.and \\
& \\
& \\
79 & \\
79 &
\end{tabular}

\section{Sentence}

Sentence

25 years plus 12 years

not guilty

not guilty

10 years

not guilty

25 years plus 35 years

not guilty

5 years

5 years

5 years

15 years

16 years

5 ycars plus 2 years not guilty

10 years

25 years plus life

120 years

10 years

1 year plus 5 years

5 years

not guilty

5 years

not guilty

5 years

15 years

litie \& $\$ 5000$ tine plus

high

low

low

low

high

low medium

Jury total

Jurors with experience

medium $\quad 23 \quad 7$

medium $\quad 25 \quad 9$

low $\quad 20 \quad 5$

medium $26 \quad 8$

medium $\quad 22 \quad 8$

low 22

low 21

medium $\quad 25 \quad 8$

high $\quad 36$

11

high $\quad 29$

6

$\begin{array}{lll}\text { medium } & 32 & 8\end{array}$

low $\quad 30 \quad 9$

low 34

low $\quad 29 \quad 8$

low $20 \quad 5$

low 27

high 22

medium $\quad 20 \quad 8$




\section{Kidnapping}

$79-0536$

$79-0519$

$79-0160$

$79-1214$

$79-0818$

$79-1672$

$79-0818$

$79-0554$

$78-1714$

79-0173
First Degree Battery

Keeping a Gambling House

First Degree Battery

Aggravated Robbery

Aggravated Robbery

Aggravated Robbery

Second Degree Murder

(Habitual Offender)

First Degree Murder

Aggravated Robbery

(Habitual Offender)

Second Degree Murder life $\$ 5000$ tinne plus

life and $\$ 5000$ finc

10 years

medium

38

1 ycar

3 years probation

low

low

\$15.000 fine

low

low

low

not guilty

35 years

high

medium

medium

25

25 ycars

not guilty

low
11 